\title{
П.П. Румянцев
}

\section{ЖАНДАРМСКИЙ НАДЗОР ЗА ЯРМАРКАМИ В СИБИРИ В ХІХ в.}

\author{
Исследование выполнено при финансовой поддержке гранта Президента РФ для молодых российских ученых \\ (проект МК-2135.2018.6).
}

\begin{abstract}
Исследуется обстоятельства появления надзора со стороны жандармского ведомства за проходящими в Сибири ярмарками. Выявляются те ярмарки, на которых требовалось обязательное жандармское присутствие. Выячняются функции, выполняемые жандармскими чинами во время занятия ими должности временного коменданта на ярмарках. Определены причины свертывания этого надзора.

Ключевые слова: жандармерия; штаб-офицеры; Сибирь; надзор; ярмарки; торговля; ХІХ в.
\end{abstract}

В обыденном сознании деятельность российских жандармов ассоциируется с тайной полицией, занятой исключительно борьбой с оппозиционными движениями, преследуя задачу защиты правящей власти от всех на нее посягательств. Однако жандармерия оказалась очень удобным инструментом в руках правительства по осуществлению надзора за различными сферами социально-экономической жизни. Жандармские чины занимали независимую от местной власти позицию, получая высокое денежное содержание, подчиняясь только своему жандармскому руководству, что давало основание надеяться на объективность их расследования и заинтересованность в своей службе. Поэтому неудивительно, что жандармов стали привлекать к политике государственного надзора, возлагая на них разного рода как секретные, так и открытые миссии. Одной из таких возложенных на сотрудников Корпуса жандармов задач являлось выполнение обязанностей временных комендантов на ярмарках, на основе проведения которых в первой половине XIX в. строилась торговая система в Российской империи. В отечественной историографии эта функция жандармерии изучена фрагментарно [1. С. 103-111; 2. С. 268], поэтому в представленной статье будет предпринята попытка исследования деятельности жандармских чинов в этом направлении на примере Сибирского региона, на территории которого ярмарки имели свою специфику, что будет способствовать раскрытию одной из слабоизученных сторон в деятельности политической полиции Российской империи.

Вопросы, связанные с торговой деятельностью, в том числе и за Уралом, попали в поле зрения жандармского ведомства практически сразу после учреждения в 1827 г. Корпуса жандармов. Проводивший в 1829 г. секретную миссию по обзору положения государственных преступников в Сибири подполковник А.П. Маслов обратил внимание на множество других вопросов и проблем региона, о чем он не преминул доложить своему начальству. Так, в одной из своих записок под названием «Общие замечания о Сибири. О средствах к улучшению благосостояния поселян, городов и инородцев в Сибири» он рассуждал о пользе и вреде самой крупной в регионе ярмарки - Ирбитской. Маслов пришел к неутешительному выводу, что эта ярмарка, «установленная собственно для удобнейшего сбыта сибирских произведений, соединив в одной точке всю промышленность во вред Сибири, более благоприятствует торговле внутренних российских городов». По мнению жандармского чина, гораздо выгоднее для Сибирского региона было бы перенести эту ярмарку вглубь Сибири, например в Тюмень или Тобольск, что со временем приведет к развитию мануфактурного производства и хлебопашества, «словом, оживит торговлю, искусства, мануфактуры и предприимчивость здешнего купечества». Более того, Маслов выражал надежды, что приезжающие на ярмарку из европейской части страны купцы и дворяне могли бы способствовать улучшению нравственного климата внутри самой Сибири, «увеличили бы день ото дня европейскую образованность, мало здесь еще известную, и, смягчив нравы, распространили бы круг познаний и деятельность в торговом искусстве». В начале 1830 г. предложения Маслова шеф жандармов А.Х. Бенкендорф переслал на рассмотрение министру финансов Е.Ф. Канкрину, от которого в то же время пришел ответ, что предложение об «уничтожении» Ирбитской ярмарки нетолько не справедливо, но и вовсе несбыточно, поэтому никаких перемен здесь не последует [3. Л. 32 об.- $-33,38,42]$.

В 1833 г. был создан новый жандармский округ 7-й (с 1837 г. 8-й), в состав которого вошли все сибирские губернии. Во главе округа был поставлен только что упоминавшийся Маслов, но уже в чине полковника, а также имевший опыт службы на такой должности, поскольку до этого назначения на протяжении трех лет он стоял во главе 5-го жандармского округа. В августе этого же года вышло утвержденное царем положение о возложении на жандармских штаб-офицеров обязанностей временных комендантов в тех городах и местечках, где устраивались ярмарки. В законе не были четко 
определены обязанности чинов Корпуса жандармов при исполнении этой должности, только указана размытая формулировка - «со всеми правами, званию сему присвоенному» [4. С. 499-500]. Жандармское присутствие на ярмарках закреплялось в вышедшем в 1836 г. Положение о Корпусе жандармов, где говорилось, что губернские жандармские команды можно использовать для сохранения порядка во время общественных мероприятий, в том числе и на ярмарках [5. C. 776].

Внимание жандармского ведомства к торговой деятельности можно объяснить попыткой установления правительственного надзора за торгово-промышленной сферой в целом, как это уже было сделано за чиновничьим аппаратом. Корпус жандармов являлся очень удобным инструментов в руках правительства для осуществления политики надзора. Жандармские чины не подчинялись местной исполнительной власти, следовательно, не зависели от нее. Довольно высокое денежное содержание по сравнению с представителями других правительственных учреждений, в том числе и по военному ведомству, давало основания надеяться на честность и объективность жандармов при исполнении возложенных на них служебных обязанностей. В 1841 и 1842 гг. будет установлен надзор со стороны жандармского ведомства за частной золотопромышленностью в Сибири, главной промышленной отрасли региона, поставлявшей подавляющую частью всего добываемого в стране золота, и на сибирских приисках появятся должности двух жандармских штаб-офицеров один находился на приисках Западной Сибири, второй - на приисках Восточной Сибири [6]. Тем самым, жандармский надзор вводился за целой региональной отраслью производства, где трудилось большое количество наемных работников, численность которых в разные годы достигала 30 тыс. человек. Вместе с тем торговля и прежде всего ярмарки в Сибири также привлекали внимание центральной власти.

Проводимые на территории Сибири ярмарки имели свои особенности. Во-первых, натуральный характер хозяйства местного населения отражался в слаборазвитых в регионе товарно-денежных отношениях. Как следствие, коренному и русскому населению в Сибири вполне было достаточно проведения одной ярмарки в год на конкретной территории и в конкретное, как правило осенне-зимнее, время. Во-вторых, главным товаром сибирских ярмарок с момента их появления и вплоть до середины XIX в. являлась пушнина, добываемая в основном коренным населением и сбываемая ими либо мелким торговцам, либо продаваемая самими аборигенами во время приезда их на ярмарки. В последствии приобретенная у местного населения пушнина перепродавалась на других, более крупных ярмарках, но уже с существенной наценкой. Пушной товар из Сибири очень высоко ценился как на внутренних рынках России, так и за ее пределами. Поэтому привлечение чинов Корпуса жандармов к надзору за ярмарочной сетью в Сибири помимо необходимости соблюдения порядка во время торговли можно объяснить еще и желанием правительства сохранить пушнину в качестве основного поставляемого из Сибири товара, что демонстрируют выявленные нами архивные документы. Позиция начальника Корпуса жандармов в решении затрагивавших интересы Сибири вопросов имела большое значение по той причине, что с января 1837 г. он являлся членом Сибирского Комитета, высшего законосовещательного органа по делам всего сибирского региона [7. Л. 1].

Деятельность чинов Корпуса жандармов имела строгую регламентацию в рамках специально принятых инструкций, начиная с инструкции 1827 г., когда и появился корпус, где четко определялись должностные обязанности жандармских чинов. Исполнение жандармами обязанностей временных комендантов во время проведения ярмарок не стало исключением для составления подобной инструкции. Согласно этому документу временный комендант получал широкие полномочия: он являлся непосредственным начальником всех находящихся на ярмарке воинских команд, в значительной степени ему также подчинялась местная полиция, обязанная по его требованию предоставлять разного рода информацию. Но еще больше у жандармского штаб-офицера было должностных обязанностей. Так, он должен был во все время проведения ярмарки иметь сведения обо «всех вообще приезжающих и отъезжающих» на ярмарку лиц, следить за общественным порядком, в случае беспорядков немедленно прекращать их, также не допускать проведения каких-либо азартных игр. Временному коменданту вменялась защита торговцев от притеснений их со стороны местной полиции, но при этом он также должен был следить, чтобы торговцы продавали качественный товар и использовали узаконенные меры веса. Однако исполнительными функциями жандармские штаб-офицеры на ярмарках не наделялись: в случае неповиновения они не могли подвергать наказанию виновных, это находилось в прерогативе начальства провинившихся лиц, о случаях нарушений со стороны гражданских чиновников и «прочих лиц невоенных» жандармы обязывались доносить местным исправникам и городничим для принятия соответствующих мер. Помимо донесений местному начальству обо всех происшествиях жандармскому чину ставилось в обязанность «обо всем доносить по команде Шефу жандармов» [8. Л. 6-8]. Таким образом, исполнение обязанности временного коменданта во время проведения ярмарок для служащих Корпуса жандармов являлась исключительно надзорной функцией. В этой связи использовался традиционной инструмент жандармского надзора в виде отчетов, которые составлялись по окончании ярмарок и отправлялись на имя окружного жандармского начальника, а от него поступали к руководству Корпуса.

По развитию торговых отношений, как и по числу ярмарок, Сибирь существенно уступала европейской 
части страны. В 1832 г. в Сибирском регионе проходила лишь 71 ярмарка, из них в Тобольской губернии 48 , в Томской губернии - 2, в Иркутской губернии - 12, в Якутской области - 6, в других местах -3 , в то время как в Европейской России зафиксировано 3558 ярмарок [9. С. 91]. Известный имперский финансист и статистик Ю.А. Гагемейстер, ссылаясь на официальные данные, приводил следующие сведения о количестве ярмарок в Сибири на 1851 г.: Тобольская губерния 81, Томская - 5, Енисейская - 17, Иркутская - 40, Забайкальская - 14, Якутская - 9, всего - 166 ярмарок. В совокупности на всех этих ярмарках было продано товара на сумму 3078818 руб., что не идет ни в какое сравнение с одной только Ирбитской ярмаркой, на которой в этом же году продажа товара достигла цифры 29362950 руб. [10. С. 575, 578]. В последующие годы количество ярмарок на территории всей Сибири будет постоянно увеличиваться и к концу XIX в. достигнет около 700 с общим торговым оборотом более 40 млн руб., при этом подавляющая часть ярмарок так же, как и ранее, будет проходить на территории Тобольской губернии [9. С. 148].

Присутствие жандармского штаб-офицера на всех ярмарках империи представлялось крайне затруднительным по причине большого числа проводимых ярмарок и небольшого количества жандармских чинов как правило, штаб-офицер Корпуса жандармов в каждой губернии был один (в чине от майора до полковника включительно). Поэтому практически сразу же стали создаваться расписания или перечень основных ярмарок, на которых требовалось присутствие жандармских штаб-офицеров, при этом на ярмарки могли отправляться не только штаб-офицеры, но и младшие их по званию обер-офицеры (поручики, штабс-капитаны и капитаны). Первоначально присутствие служащих в Сибири жандармских чинов требовалось только на одной, самой крупной ярмарке - Ирбитской, проходившей в одноименном городе, расположенном в Пермской губернии (несмотря на то что территориально эта губерния не относится к Сибирскому региону, она с 1836 по 1858 г. входила в состав 8-го, сибирского жандармского округа). Помимо Ирбитской другими ярмарками в Сибири, подлежавшими отправке туда жандармских чинов, являлись: в Тобольской губернии - в крепости Обдорской (время проведения - декабрь и январь), в Томской губернии - в г. Нарым (май и июнь) и Иркутской губернии - в слободе Кяхта (январь или февраль) [11. Л. 16 об.].

Ирбитская ярмарка представляла для жандармского ведомства первостепенное значение по причине своих больших оборотов, поэтому туда в первую очередь и командировались жандармские чины. Во второй половине 30-х гг. XIX в. ежегодно обязанности временного коменданта на Ирбитской ярмарке исполнял начальник Тобольской жандармской команды, штабс-капитан Лыткин. Шеф жандармов Бенкендорф высоко оценивал его действия на указанной должности, объявляя ему благодарность за расторопность, предупреждение беспорядков, за личное присутствие в решении споров, а также за содержание вверенной ему жандармской части в отличном состоянии [12. № 38 от 13 июня].

Жандармское начальство, помимо выражения благодарности своими подчиненным за исполнение возложенных на них обязанностей временных комендантов на ярмарках, также стремилось к их материальному поощрению, указывая на важность выполняемых ими обязанностей. В начале 1840 г. Бенкендорф обратился к министру финансов Е.Ф. Канкрину с ходатайством о единовременном денежном награждении начальника Тобольской жандармской команды штабс-капитана Лыткина за командировку его с командой в течение 5 лет на Ирбитскую ярмарку для наблюдения за порядком и независимо от этого об определении постоянного пособия тем жандармам, которые будут в дальнейшем туда командироваться. Канкрин приказал сделать от Минфина в Комитет министров представление о награждении штабс-капитана Лыткина получаемым им годовым окладом жалованья в размере 285 руб. сер. за 5 лет командировок на Ирбитскую ярмарку. Далее Канкрин передал главе Министерства внутренних дел графу А.Г. Строганову просьбу Бенкендорфа о назначении постоянного пособия тем жандармам, кто командируется с командой на указанную ярмарку. Необходимые для этого деньги, по мнению Канкрина, можно брать из городских доходов г. Ирбита от проведения ярмарки, ежегодно собираемых по 40-45 тыс. руб. Не получив ответа на свою просьбу, Бенкендорф сам дважды в течение 1840 г. обращался к главе МВД со своим мнением, что командируемым на Ирбитскую ярмарку жандармским офицерам можно назначить в пособие на время такой командировки по 4 руб. асс. в день столовых денег из того же источника, указанного министром финансов. Вопрос этот разрешился в конце года, когда пермский гражданский губернатор доложил главе МВД, что на предложение об ассигновании денег на содержание жандармского чина из доходов, получаемых с Гостиного двора в Ирбите, купеческое общество, кому принадлежит этот двор, дало свое согласие [13. Л. 1-1 об., 6-6 об., 9, 13].

В следующие годы, как видно из выявленных нами документов, на Ирбитскую ярмарку командировались уже жандармские чины из самой Пермской губернии. Так, в 1844 г. высшее жандармское начальство объявило благодарность начальнику Пермской жандармской команды капитану Орлову за исполнение в этом же году должности временного коменданта на Ирбитской ярмарке, на которой он «обратил на себя особенное внимание примерным усердием и бескорыстными действиями, способствуя развитию торговой промышленности и соблюдению тишины и порядка» [14. № 38 от 8 мая]. В сохранившемся отчете о проведении ярмарки за 1845 г. указано, что в этом же году обязанности временного коменданта на ней исполнял находящийся в Пермской губернии жандармский штаб-офицер майор фон 
Вендрих. Последний докладывал начальнику 8-го (Сибирского) жандармского округа генерал-майору К.И. Влахопулову, что за время проведения ярмарки (с 15 февраля по 15 марта) не случилось каких-либо серьезных происшествий, заслуживающих внимания и сообщения о них. Из второстепенных происшествий выделялись мелочное воровство на общую сумму 291 руб. 84 коп. сер., что являлось, по мнению фон Вендриха, небольшим показателем, и заслуга в этом принадлежит действиям находящейся во время проведения ярмарки Пермской жандармской команды во главе с упомянутым капитаном Орловым и 13 его подчиненными нижними чинами. Сверх этого за пьянство, кражу и мошенничество было взято под присмотр 39 человек, за неплатеж денег - 4 человека, также произошло два пожара, потушенные в самом начале [15. Л. 2].

Помимо информации о происшествиях майор фон Вендрих приводил информацию об основных торгуемых на ярмарке товарах, о ценах на них по сравнению с прошлыми годами. В самом конце прикладывался ряд ведомостей, служивших дополнением к его отчету. В первой ведомости в виде таблицы указывался торговый оборот ярмарки, где расписывались основные товары. По этой ведомости следовало, что привезено товаров было на сумму 20423609 руб. сер., а продано на 17412522 руб. сер. С ярмарки поступили следующие доходы в пользу казны: с торговой площади за раздачу мест - 5744 руб. 25 коп.; за проданную из Казначейства гербовую бумагу - 6123 руб. 70 коп.; в пользу города и горожан - 2693 руб. 74 коп.; обывателям от квартирования и продовольствия приезжих - 39500 руб., всего же доходы с ярмарки составили 54061 руб. 69 коп. Далее шла ведомость о бывших на ярмарке купцах с разделением их по гильдиям и не записанных в гильдии, но производивших торговлю: купцов первой гильдии 21 чел., второй - 98, третьей - 399 чел., других категорий населения, ведших торговлю, - 12758 чел., также на ярмарке зарегистрировано было 25630 чел. извозчиков и крестьян из окрестных мест. Третья ведомость - об иностранцах на ярмарке (всего 22 чел.). Затем шел список бывших на ярмарке военных штаб- и оберофицеров - 6 чел. И, наконец, последней была ведомость о чиновниках гражданского ведомства - 40 чел. Всю эту информацию начальник округа 8 июня 1845 г. переслал Шефу жандармов [15. Л. 1-10].

С середины 40-х гг. Ирбитская ярмарка переходит из ведения 8-го (Сибирского) жандармского округа к 7-му, состоящему из поволжских губерний со штаб-квартирой округа в Нижнем Новгороде. Соответственно, командироваться на эту ярмарку стали уже чины 7-го жандармского округа. Скорее всего, это следует связать с тем, что в Нижнем Новгороде проходила самая крупная в стране ярмарка, именуемая Макарьевская, а Ирбитская считалась по оборотам второй после нее, между самими ярмарками имелись тесные контакты; логично было вести надзор за двумя крупнейшими ярмарки чинам одного и того же территориального жандармского ведомства.
Другой ярмаркой на территории Западной Сибири, подлежащей надзору со стороны жандармского ведомства, была ярмарка, устраиваемая в Обдорской крепости (ныне г. Салехард). Ее особенности заключались в крайней удаленности от Омска, административного центра Западно-Сибирского генерал-губернаторства, а также, что на этой ярмарке доминировали представители коренного населения, а основным товаром являлась пушнина. При этом сами жандармские чины называли ее даже не ярмаркой, а рынком, «на котором инородцы делают свои годовые запасы, состоящие в печеном хлебе, муке, котлах, сырых кожах, листовом табаке, удах, мережах для рыбной ловли и еще в некоторых незначащих вещах. Торговцы от них приобретают большей частью тоже незначительные вещи, малоценную рухлядь и весьма малое количество лисиц» [16. Л. 206 об.-207]. Таким образом жандармские чины отмечали небольшой торговый оборот этой ярмарки, не шедший ни в какое сравнение с Ирбитской ярмаркой. Из наблюдений жандармов выходило: одной из причин «слабого хода» ярмарки является тот факт, что «инородцы считают своей честью торговать только со своими или отца своего знакомыми и ни за что не согласятся иметь дело с чужими». По этой причине, делали они вывод, торговцы предпочитают со своим товаром ездить на Ирбитскую ярмарку [Там же. Л. 208 об., 209].

В качестве подтверждения небольших торговых оборотов Обдорской ярмарки можно привести сведения из жандармских отчетов. Так, в отчете за 1864 г. исполнявший обязанности временного коменданта на ярмарке тобольский жандармский штаб-офицер, полковник Заранек сообщал, что в этом году на ярмарку русскими торговцами было привезено товаров на сумму 34305 руб. 76 коп., продано же на сумму 3181 руб. 20 коп., выменено у инородцев товаров на сумму 19041 руб. 50 коп., таким образом, товаров осталось на сумму 12084 руб. 06 коп. В то же время количество привезенных инородцами товаров составило сумму 29890 руб. 60 коп., из привезенных товаров продано русским на 12935 руб. 40 коп., выменено у русских на их товар и отдано им за долги на 14118 руб. 30 коп., поступило в ясак и на повинность 2836 руб. 90 коп. [17. Л. 7 об.-8, 10 об.-11].

Региональная исполнительная власть пыталась использовать жандармское присутствие на ярмарках для защиты казенных интересов в вопросе взимания ясака с коренного населения. В декабре 1844 г. генералгубернатор Западной Сибири, князь П.Д. Горчаков специальным отношением обращался к тобольскому жандармскому штаб-офицеру, майору Петровскому, прося его во время исполнения обязанности временного коменданта на Обдорской ярмарке следить за взносами инородцев ясака натурой и запрещении вести им торговые отношения до окончательного взноса ясака [16. Л. 185]. Данные правила вступили в силу в 1843 г. после ревизии сенатора Толстова, в ходе которой был зафиксирован массовый характер неуплаты инородца- 
ми ясака в казну по причине того, что инородцы стремились добытую пушнину торговать, получая от этого гораздо бо́льшую выгоду. Майор Петровский порученные обязательства выполнил, но вместе с тем не преминул сообщить, что хотя сбор ясака с инородцев «заключает в себе довольно важный предмет для наблюдения офицера Корпуса жандармов», однако со стороны местного губернского начальства ежегодно командируются особые чиновники для наблюдения за сбором ясака, вполне справляющиеся с этой задачей [18. Л. 4 об.].

Не могли жандармские чины обойти фактора дальнего расстояния места проведения ярмарки и тех трудностей, с которыми они сталкивались, добираясь до этих мест. Так, в феврале 1857 г. начальник 8-го (Сибирского) жандармского округа генерал-майор Казимирский описывал лишения, стоящие на пути его подчиненных, следующим образом: «Ибо не говоря уже об огромном расстоянии более 2060 верст в один только конец, он [жандармский офицер] подвергался весьма лишениям в совершенно пустынной стране, где в особенности от Березова до Обдорска, нет никакого пути сообщения и езда совершается на оленях при жестоких морозах и где на станциях имеется только юрта для проезжающих, в которой ни обогреться, ни укрыться от непогоды нет никакой возможности». Казимирский выступал за материальное поощрение жандармских чинов за переносимые ими трудности при исполнении обязанности временного коменданта на ярмарке в Обдорске [19. Л. 1 об.].

Исходя из фактора дальнего расстояния, незначительных торговых оборотов на самой ярмарке, окружное жандармское начальство в Сибири выступало за освобождение жандармских чинов от надзора за сбором ясака во время проведения ярмарки, а главное, сделать обязательным посещение жандармским офицером Обдорской ярмарки не ежегодно, а раз в три года. Министр внутренних дел в 1845 г. поддержал оба этих предложения, и в следующее время жандармский чин отправлялся в Обдорск на ярмарку раз в три года, уже не ведя надзор за сбором ясака [18. Л. 4 об., 11].

Однако жандармские чины держали вопрос о выплате ясака в поле своего зрения. Более того, видя, что из года в год сокращается взнос пушнины в качестве ясака в казну, жандармские офицеры выступали за его ликвидацию. В 1857 г. адъютант жандармского штабофицера в Омской области штабс-капитан Борщов докладывал своему начальству, что если бы инородцам предоставить право платить подать в денежном виде и дозволить вести торговые отношения с русским купечеством в течение всего года, это крайне благоприятно скажется на развитии местной торговли и более того, «через частные сношения с русскими дошло бы до инородцев гораздо скорее просвещение. Без этой меры инородцы останутся в том же диком и грубом состоянии, в котором они находятся слишком сто лет тому назад и в котором находятся до настоящего времени» [19. Л. 7-7 об.]. Однако это предложение так и не будет исполнено и коренное население Сибири вплоть до начала XX в. продолжит уплату ясака в натуральном виде.

Существовали в Сибири ярмарки, не входившие в перечень обязательных ярмарок для командирования туда жандармских чинов в качестве временных комендантов, однако, по мнению местного жандармского начальства, туда следовало бы отправлять жандармских чинов. В ноябре 1856 г. начальник 8-го (Сибирского) жандармского округа генерал-майор Казимирский докладывал шефу жандармов князю В.А. Долгорукову, что у проводимой в городе Ишиме Тобольской губернии так называемой Никольской ярмарки было увеличено время проведения с 10 до 25 дней, а также указывались ее большие торговые обороты (в 1855 г. на ярмарку привезли товаров на сумму 1436435 руб. сер., из них продано на 1158870 руб. сер.). Исходя из приведенных сведений, Казимирский испрашивал разрешения о включении этой ярмарки в список тех ярмарок, на которых жандармские штаб-офицеры обязаны исправлять должность временного коменданта. Отношением от 28 ноября 1856 г. шеф жандармов дал согласие на просьбу Казимирского и просил его сделать распоряжение о ежегодном командировании на эту ярмарку жандармского штабофицера Тобольской губернии [20. Л. 1-3].

Последовавшие от жандармских чинов сообщения подтверждали большие торговые обороты Ишимской ярмарки и большое количество присутствующих на ней людей. В феврале 1859 г. жандармский штаб-офицер в Тобольской губернии полковник фон Колен докладывал начальнику 8-го (Сибирского) жандармского округа генерал-майору Казимирскому, что по итогам прошедшей в декабре 1858 г. ярмарки в Ишиме всего было привезено товаров на сумму 2661065 руб. сер., из них продано на 2417780 руб. и осталось нераспроданного товара на сумму 243285 руб. сер. Ишимский ярмарочный комитет от проведения ярмарки получил следующий доход: с временных балаганов - 2628 руб. 50 коп., с аренды принадлежащих городу мест - 612 руб. 24 коп., гостиницы - 15 руб., извозчиков - 15 руб., всего - 3270 руб. 74 коп. Торговцев на ярмарке находилось следующее количество: купцов всех трех гильдий - 67 чел., разночинцев - 1945 , помимо них приезжало на ярмарку военных чиновников - 5 и гражданских - 11, всего же - 2028 чел. [21. Л. 17-20].

Развитию торговли, а вместе с ней и самой ярмарки в Ишиме способствовало удачное географическое расположение этого места. Ишимский уезд размещался на самом юге Тобольской губернии, территориально близко к Уральскому региону. Ближе к Уралу располагался только Курганский уезд той же Тобольской губернии, в котором также действовала своя ярмарка, выступающая конкурентом Ишимской, что незамедлительно сказывалось на торговых оборотах последней о чем не преминули сообщить жандармы. В 1865 г. исполнявший обязанности временного коменданта на этой ярмарке тобольский жандармский штаб-офицер, 
полковник Заранек доносил своему окружному жандармскому начальству, что сокращение лавочной торговли на Ишимской ярмарке связано с проведением в это же время еще двух ярмарок по соседству - Пресновской ярмарки в 250 верстах от Ишима и в крепости Звериноголовской Оренбургской губернии на границе Курганского округа. В доказательство жандармский чин приводил цифры падения торгового оборота на Никольской ярмарке в 1864 г. по сравнению с прошлыми годами: привезено товаров на 1745075 руб., продано на 1152325 руб., осталось непроданных товаров на 592750 руб. Главными товарами являлись «животные продукты: кожа, сало и мясо». Это свидетельствует, что ярмарка имела сельскохозяйственный характер. Заранек отмечал, что многие приезжающие торговцы раньше времени прекращают свои торги, чтобы успеть в Курган на местную ярмарку. По мнению полковника Заранека, поддержанного начальником 8-го (Сибирского) жандармского округа генералмайором Политковским, следовало бы изменить срок проведения Никольской ярмарки в Ишиме, сдвинув ее на начало декабря, тем самым развести ее по времени с Курганской ярмаркой. Шеф жандармов поддержал предложение своих подчиненных, обратившись в феврале 1865 г. к министру внутренних дел П.А. Валуеву. От последнего пришел ответ, что изменение сроков проведения ярмарок делается по ходатайству городских обществ или ярмарочных комитетов; так как ни от Ишимского, ни от Курганского обществ и торговцев не поступало подобных заявок, то министр затрудняется сделать какие-либо распоряжения по этому предмету [20. Л. 5-6 об., 10-12]. Таким образом время проведения ярмарок осталось неизмененным.

В Восточной Сибири единственной ярмаркой, обязательной для отправки туда жандармского офицера в качестве временного коменданта, являлась Кяхтинская. Такой выбор был обусловлен рядом факторов. Кяхта была центром русско-китайской торговли, где главным товаром являлся чай, развозимый оттуда по всей России. В конце XVIII в. из Иркутска в Кяхту была перенесена таможня. Близость города к китайской границе оборачивалась проблемой контрабанды товаров, незаконного пересечения границы. Нельзя не упомянуть, что Кяхта располагалась в Забайкальском регионе, традиционном месте ссылки государственных преступников, в том числе и участников декабрьского выступления 1825 г. Все сказанное привлекало внимание жандармского ведомства к этому городу и проходящей там торговой деятельности. В августе 1836 г. генералгубернатор Восточной Сибири С.Б. Броневский отправил шефу жандармов Бенкендорфу отношение, в котором он перечислил разного рода злоупотребления со стороны местной власти и происшествия в Якутске, Нерчинске и Кяхте, прося в конце документа назначить в названные места жандармских чинов для поддержания там законного порядка. В октябре того же года Бенкендорф сообщил Броневскому, что по составлен- ному им для царя докладу последовала монаршая воля отказать в просьбе генерал-губернатора, вместе с тем, Николай I соизволил в распоряжение Броневского командировать на время из Корпуса жандармов одного штабофицера и одного обер-офицера для ревизии указанных мест. Также царь повелел, чтобы такие командировки в последующем стали практикой [22. Л. 1, 3, 9-11].

В начале 1838 г. в Иркутск прибыли командированные туда в распоряжение местного генерал-губернатора подполковник Корпуса жандармов Ливенцов и адъютант жандармского штаб-офицера в Эстляндской губернии штабс-капитан Вершеневский. Новый генерал-губернатор Восточной Сибири В.Я. Руперт дал им тщательную инструкцию, на что следует обратить внимание, в том числе указал на необходимость вести наблюдение за ярмаркой в Кяхте и в целом за развитием там торговли. В 1839 г. оба жандармских офицера представили сведения о проделанной ими в регионе работе. Ливенцов, в частности, сообщал, что ярмарка в Кяхте, ранее открываемая в январе, с каждым годом начинается все позже по причине «несвоевременного доставления товаров московскими купцами», отчего происходят большие убытки. Ливенцов настоял, а генерал-губернатор сделал распоряжение, чтобы Кяхтинская ярмарка начиналась с 1 января или даже с декабря. Штабс-капитан Вершеневский по поручению генералгубернатора Руперта исполнял обязанности временного коменданта на ярмарке в Якутске, проходившей в конце июня - начале июля 1838 г. Сам же Руперт выступил против предложения своего предшественника на генерал-губерна-торском посту Броневского об утверждении постоянного жандармского присутствия в Якутской области и Охотском крае, считая что жандармский чин там необходим «только на время бывающей там ярмарки < ..> для наблюдения благочиния и отвращения случаев к разным притеснениям», но с этой задачей, по его мнению, может справляться жандармский штаб-офицер в Иркутской губернии, командируемый ежегодно в указанные местности. Шеф жандармов выступил против этой идеи, считая, что такая командировка обойдется дорого и будет продолжительной по времени, отвлекая губернского жандармского штабофицера от более важных дел, поэтому он предложил отправлять на эту ярмарку гражданских чиновников из жандармского ведомства для поддержания там порядка [22. Л. 51, 141-141 об., 167 об., 186-189].

Ярмарка в Кяхте вошла в расписание ярмарок, где требовалось присутствие жандармских чинов в качестве временного коменданта. Ее особенностями можно назвать иностранный характер торговли, прежде всего с Китаем, а также тесную связь ярмарочной торговли с таможней. В последующие годы туда командировались либо адъютант жандармского штаб-офицера в Иркутской губернии, либо сам штаб-офицер, следившие за порядком на этой ярмарке, в том числе и за деятельностью местной таможни, и доносившие своему начальству о результатах ее проведения, а также с их стороны 
поступали предложения по совершенствованию проведения ярмарки и искоренению там беспорядков (подробнее об этом см.: [23]).

Расписание ярмарок, где требовалось присутствие жандармского офицера, со временем претерпевало изменения, какие-то ярмарки удалялись, взамен появлялись новые. Окончание исполнения жандармскими чинами обязанности временного коменданта на ярмарках приходится на конец 60-х гг. ХІХ в. Циркулярным отношением от 28 августа 1867 г. за № 280 шеф жандармов П.А. Шувалов уведомил начальника жандармского округа в Сибири генерал-майора Политковского, что вследствие новых правил жандармские штабофицеры уже не обязаны исправлять должности временных комендантов на важнейших ярмарках, тем не менее, они должны наблюдать за всем происходящим на них и доносить как о ходе торговли, так и о «замечательных событиях на таковых ярмарках». В своем ответе от 16 сентября Политковский сообщил, что во вверенном ему округе проходят всего две ярмарки, подлежащие отправке туда чинов Корпуса жандармов, - в городах Ишиме и Березове, где тобольский жандармский штаб-офицер исправляет должность временного коменданта - в первом ежегодно, а в последнем раз в три года. Политковский спрашивал у шефа жандармов, следует ли по-прежнему командировать на эти ярмарки тобольского штаб-офицера «для собирания сведений о ходе торговли и о замечательных событиях на этих ярмарках или же ограничиться испрашиванием таковых сведений от местной полиции?». На этот вопрос Шувалов ответил, что если Тобольский губернский воинский начальник не будет находиться на тех ярмарках, на которых штаб-офицер Корпуса жандармов должен исправлять обязанность временного коменданта, то жандармскому чину следует исполнять эту обязанность впредь до последующего по этому предмету общего распоряжения [24. Л. 9-10].

Исключение из функционала жандармерии обязанности временных комендантов на крупных ярмарках в империи было связано с тем, что в сентябре 1867 г. с принятием нового положения о Корпусе жандармов произошла реорганизация самого жандармского ведомства, согласно которой вместо должностей губернских жандармских штаб-офицеров создавались губернские и уездные жандармские управления, несшие исключительно наблюдательные обязанности [25. С. 76]. Жандармерия превращалась в орудие политического сыска в борьбе с революционным движением, и первоочередными задачами для нее становились защита самодержавия от посягательств изнутри страны. Часть функций Корпуса жандармов, как, например, выявление фальшивомонетчества, отходила на второй план, а некоторые, как исполнение обязанности временных комендантов при проведении крупных ярмарок в империи, убирались из поля деятельности жандармов.

Таким образом, исполнение обязанностей временных комендантов на проходящих в Сибири ярмарках являлось важной функцией в деятельности чинов Корпуса жандармов на протяжении второй трети XIX в. На время проведения ярмарок на жандармов возлагались большие обязанности. Жандармские офицеры не только следили за общественным порядком, но также наблюдали за ходом торгов, являясь посредниками в случае возникших на торговой почве конфликтов. Об итогах ярмарок они обязывались докладывать своему начальству. Выбор ярмарок для посещения их жандармами во многом обусловливался торговыми оборотами этих ярмарок, доступностью для посещения их служащими Корпуса жандармов, а также необходимостью соблюдения казенных интересов, как на ярмарке в Обдорске, где торговали пушниной и собирался ясак с коренного населения, а в Кяхте ярмарка была тесным образом связана с таможенной деятельностью. Последнее обстоятельство дает основание утверждать, что жандармский надзор являлся активно используемым инструментом в правительственной политике по контролю за торгово-промышленной сферой. Сами же жандармские чины старались неформально исполнять возложенные на них обязанности временных комендантов, но, как это показывают сохранившиеся их рапорты, стремились к улучшению торговой деятельности, отмечая возможные от нее выгоды для местного населения.

\section{ЛИТЕРАТУРА}

1. Романов В.В. Функционирование местных подразделений политической полиции в условиях проведения ярмарок в $1825-1860$ гг. // Правовая политика и правовая жизнь. 2010. № 1. С. 103-111.

2. Пасечников И.А. Деятельность органов политической полиции Таврической губернии в годы Крымской (Восточной) войны (1853-1856) // Пространство и Время. 2015. № 1-2 (19-20). С. 267-272.

3. Государственный архив Российской Федерации (ГАРФ). Ф. 109. Оп. 170. Д. 58.

4. «О исправлении должности комендантов штаб-офицерами Корпуса жандармов в городах и местечках, где бывают ярмарки» (31 августа 1833 г.) [№ 6410] // Полное собрание законов Российской империи. Собр. 2-е. СПб., 1834. Т. 8. Отд. 1-е. (1833 г.). С. $499-500$.

5. «Высочайше утвержденное положение о Корпусе Жандармов» (1 июля 1836 г.) [№ 9355] // ПСЗРИ. Собр. 2-е. Т. 11. Отд. 1-е (1836). СПб., 1837. С. 771-783.

6. Бибиков Г.Н., Бакшт Д.А. Учреждение жандармского надзора на золотых приисках Сибири в 1841-1842 гг. // Вестник Томского государственного университета. История. 2016. № 3 (41). С. 16-24. DOI: 10.17223/19988613/41/3

7. ГАРФ. Ф. 110. Оп. 2. Д. 647.

8. Российский государственный исторический архив (РГИА). Ф. 1287. Оп. 6. Д. 1427.

9. Щеглова Т.К. Ярмарки юга Западной Сибири в XIX - начале XX века. Из истории формирования и развития всероссийского рынка. Барнаул, $2001.504 \mathrm{c}$.

10. Гагемейстер Ю.А. Статистическое обозрение Сибири. СПб., 1854. Ч. 2. 697 с.

11. РГИА. Ф. 1286. Оп. 10. 1846 г. Д. 729.

12. Россия. Отдельный корпус жандармов. Приказы по корпусу жандармов за 1836 г. СПб., 1837. 
13. РГИА. Ф. 1287. Оп. 31. Д. 253.

14. Россия. Отдельный корпус жандармов. Приказы по корпусу жандармов за 1844 г. СПб., 1845.

15. ГАРФ. Ф. 109. Оп. 185. Д. 129.

16. Исторический архив Омской области (ИАОО). Ф. 3. Оп. 12. Д. 17722.

17. ИАОО. Ф. 3. ОП. 4. Д. 5982.

18. ГАРФ. Ф. 109. Оп. 185. Д. 110.

19. ГАРФ. Ф. 109. Оп. 197. Д. 134.

20. ГАРФ. Ф. 109. Оп. 196. Д. 255.

21. ГАРФ. Ф. 109. ОП. 198. Д. 263.

22. ГАРФ. Ф. 110. Оп. 2. Д. 613.

23. Румянцев П.П. Жандармский надзор за Кяхтинской торговлей // Народы России, Сибири и стран Востока: история и современность: материалы Междунар. науч. конф., посвящ. 80-летию войны на Халхин-Голе (1939-2019 гг.) (Иркутск, 15 мая 2019 г.). Иркутск, 2019. С. $94-100$.

24. ГАРФ. Ф. 109. Оп. 207. Д. 131.

25. Высочайше утвержденное положение о Корпусе Жандармов (9 сентября 1867 г.) [№ 44956] // ПСЗРИ. Собр. 2-е. СПб., 1871. Т. 42. Отд. 2-е. (1867 г.). C. $73-80$.

Petr P. Rumyantsev. Tomsk State University (Tomsk, Russia). E-mail: petroom@mail.ru

GENDARME SUPERVISION OF FAIRS IN SIBERIA IN THE 19TH CENTURY.

Keywords: gendarmerie; headquarters officers; Siberia; supervision; fairs; trade; 19th century.

The subject of this research is the policy of government supervision of the commercial and industrial spheres of the Russian Empire in the 19th century. The object of the study is the activities of the gendarmerie corps officials that carried out that supervision. These activities of the gendarmerie are studied on the example of the supervision of fairs in Siberia, which had their own special aspects. This function of the Russian gendarmerie has been studied fragmentarily in Russian historiography.

To disclose the subject and object of the research, the following tasks were set: 1) to establish the reasons for the attention of the gendarmerie to fairs taking place in Siberia; 2) to identify those fairs that required a mandatory gendarme presence; 3 ) to establish the functions performed by the gendarmerie officials during their occupation of the post of temporary commandant at fairs; 4) to determine the reasons for disestablishing the gendarme supervision of the fairs.

The sources for writing the article were: materials from the gendarmerie and executive branch funds of the central Russian archives (State Archive of the Russian Federation, Russian State Historical Archive), legislative acts of the imperial government, as well as the gendarmerie corps orders. Many used archival materials were introduced into scientific circulation for the first time.

In the process of the research the author came to the following conclusions. Since 1833 the officials of the gendarmerie corps were appointed to the temporary commandants of the fairs, during which they received great powers and duties. The activities of the gendarmes in this position were regulated by instruction specially written for them. They also used the traditional gendarme surveillance tool in the form of reports that were compiled at the end of the fairs and were sent to the gendarmerie authorities. The gendarme officers not only monitored public order, but also monitored the course of bidding, being intermediaries in the event of trade-related conflicts. The choice of fairs to be visited by the gendarmes was largely determined by the trade turnover of these fairs, by the availability of fairs to be visited by the gendarmes, and by the needs to comply with state interests. The latter circumstance gives reason to assert that gendarme supervision was an actively used tool in government policy to control the commercial and industrial spheres. The gendarme officials themselves tried not to formally fulfill the duties of temporary commandant, but as the documents show, tried to improve trading activities, noting the possible benefits for the local population.

\section{REFERENCES}

1. Romanov, V.V. (2010) Funktsionirovanie mestnykh podrazdeleniy politicheskoy politsii v usloviyakh provedeniya yarmarok v $1825-1860$ gg. [The functioning of local political police units during fairs in 1825-1860]. Pravovaya politika i pravovaya zhizn'. 1. pp. $103-111$.

2. Pasechnikov, I.A. (2015) Political Police Activities in the Taurida Governorate during Crimean (Eastern) War (1853-1856). Prostranstvo $i$ Vremya Space and Time. 1-2 (19-20). pp. 267-272. (In Russian).

3. The State Archive of the Russian Federation (GARF). Fund 109. List 170. File 58.

4. Russia. (1834) "O ispravlenii dolzhnosti komendantov shtab-ofitserami Korpusa Zhandarmov v gorodakh i mestechkakh, gde byvayut yarmarki" (31 avgusta 1833 g.) [№ 6410] ["On the correction of the position of commandants by the head officers of the Gendarme Corps in cities and towns where there are fairs" (August 31, 1833) [No. 6410]]. In: Polnoe sobranie zakonov Rossiyskoy imperii (PSZRI) [Complete Collection of Laws of the Russian Empire (PSZRI)]. Vol. 8. St. Petersburg. pp. 499-500.

5. Russia. (1837) Vysochayshe utverzhdennoe polozhenie o Korpuse Zhandarmov (1 iyulya 1836 g.) [№ 9355] [“The Highest Approved Regulation on the Gendarme Corps" (July 1, 1836) [No. 9355]]. In: Polnoe sobranie zakonov Rossiyskoy imperii (PSZRI) [Complete Collection of Laws of the Russian Empire (PSZRI)]. Vol. 11. St. Petersburg. pp. 771-783.

6. Bibikov, G.N. \& Baksht, D.A. (2016) The establishing of gendarmerie supervision on private gold mines in Siberia in 1841-1842. Vestnik Tomskogo gosudarstvennogo universiteta. Istoriya - Tomsk State University Journal of History. 3(41). pp. 16-24. (In Russian). DOI: 10.17223/19988613/41/3

7. The State Archive of the Russian Federation (GARF). Fund 110. List 2. File 647.

8. The Russian State Historical Archive (RGIA). Fund 1287. List 6. File 1427.

9. Shcheglova, T.K. (2001) Yarmarki yuga Zapadnoy Sibiri v XIX-nachale XX veka. Iz istorii formirovaniya i razvitiya vserossiyskogo rynka [Fairs in the south of Western Siberia in the 19th - early 20th centuries. From the history of the formation and development of the all-Russian market]. Barnaul: Altai State University.

10. Hagemeister, Yu.A. (1854) Statisticheskoe obozrenie Sibiri [Statistical Review of Siberia]. St. Petersburg: [s.n.].

11. The Russian State Historical Archive (RGIA) Fund 1286. List 10. File 729.

12. Russia. (1837) Otdel'nyy korpus zhandarmov. Prikazy po korpusu zhandarmov za $1836 \mathrm{~g}$. [Russia. Separate gendarmes corps. Orders on the corps of gendarmes for 1836]. St. Petersburg: [s.n.].

13. The Russian State Historical Archive (RGIA). Fund 1287. List 31. File 253.

14. Russia. (1845) Otdel'nyy korpus zhandarmov. Prikazy po korpusu zhandarmov za $1844 \mathrm{~g}$. [Russia. Separate gendarmes corps. Orders on the corps of gendarmes for 1844]. St. Petersburg: [s.n.].

15. The State Archive of the Russian Federation (GARF). Fund 109. List 185. File 129

16. The Historical Archive of Omsk Region (IAOO). Fund 3. List 12. File 17722.

17. The Historical Archive of Omsk Region (IAOO). Fund 3. List 4. File 5982.

18. The State Archive of the Russian Federation (GARF). Fund 109. List 185. File 110. 
19. The State Archive of the Russian Federation (GARF). Fund 109. List 197. File 134.

20. The State Archive of the Russian Federation (GARF). Fund 109. List 196. File 255

21. The State Archive of the Russian Federation (GARF). Fund 109. List 198. File 263.

22. The State Archive of the Russian Federation (GARF). Fund 110. List 2. File 613.

23. Rumyantsev, P.P. (2019) [Gendarme surveillance of Kyakhta trade]. Narody Rossii, Sibiri i stran Vostoka: istoriya i sovremennost' [Peoples of Russia, Siberia and the East: History and Modernity]. Proc. of the International Conference. Irkutsk. May 15, 2019. Irkutsk. pp. 94-100. (In Russian).

24. The State Archive of the Russian Federation (GARF). Fund 109. List 207. File 131

25. Russia. (1871) "Vysochayshe utverzhdennoe polozhenie o Korpuse Zhandarmov" (9 sentyabrya 1867 g.) [№ 44956] ["The Highest Approved Provision on the Gendarme Corps" (September 9, 1867) [No. 44956]]. In: Polnoe sobranie zakonov Rossiyskoy imperii (PSZRI) [Complete Collection of Laws of the Russian Empire (PSZRI)]. Vol. 42. St. Petersburg. pp. 73-80. 